\title{
Copper(II) complexes of "polystyrene-bound DMAP" : effect of chain loading on the catalytic activity in the oxidative coupling of 2,6-dimethylphenol
}

Citation for published version (APA):

Koning, C. E., Jongsma, T., Brinkhuis, R., \& Challa, G. (1988). Copper(II) complexes of "polystyrene-bound DMAP" : effect of chain loading on the catalytic activity in the oxidative coupling of 2,6-dimethylphenol. Reactive Polymers, Ion Exchangers, Sorbents, 8(3), 255-266. https://doi.org/10.1016/0167-6989(88)90301-7

DOI:

10.1016/0167-6989(88)90301-7

Document status and date:

Published: 01/01/1988

Document Version:

Publisher's PDF, also known as Version of Record (includes final page, issue and volume numbers)

\section{Please check the document version of this publication:}

- A submitted manuscript is the version of the article upon submission and before peer-review. There can be important differences between the submitted version and the official published version of record. People interested in the research are advised to contact the author for the final version of the publication, or visit the DOI to the publisher's website.

- The final author version and the galley proof are versions of the publication after peer review.

- The final published version features the final layout of the paper including the volume, issue and page numbers.

Link to publication

\footnotetext{
General rights

- You may freely distribute the URL identifying the publication in the public portal. follow below link for the End User Agreement:

www.tue.nl/taverne

\section{Take down policy}

If you believe that this document breaches copyright please contact us at:

openaccess@tue.nl

providing details and we will investigate your claim.
}

Copyright and moral rights for the publications made accessible in the public portal are retained by the authors and/or other copyright owners and it is a condition of accessing publications that users recognise and abide by the legal requirements associated with these rights.

- Users may download and print one copy of any publication from the public portal for the purpose of private study or research.

- You may not further distribute the material or use it for any profit-making activity or commercial gain

If the publication is distributed under the terms of Article $25 \mathrm{fa}$ of the Dutch Copyright Act, indicated by the "Taverne" license above, please 


\title{
COPPER(II) COMPLEXES OF "POLYSTYRENE-BOUND DMAP" *: EFFECT OF CHAIN LOADING ON THE CATALYTIC ACTIVITY IN THE OXIDATIVE COUPLING OF 2,6-DIMETHYLPHENOL * *
}

\author{
C.E. KONING, T. JONGSMA, R. BRINKHUIS and G. CHALLA ***
}

Laboratory of Polymer Chemistry. State University of Groningen, Nijenborgh 16, 9747 AG Groningen (The Netherlands)

(Received February 17, 1987; accepted March 11, 1987)

The effect of the degree of loading, $\alpha$, of polystyrene with DMAP ligands on the catalytic activity of "polystyrene-bound DMAP". copper catalysts in the oxidative coupling of 2,6-dimethylphenol was studied. The intrinsic activity increases upon enhancing $\alpha$ from 0.096 to 0.23. This increase proved to be mainly brought about by an increasing "strain" in the polymeric catalyst. An additional accelerating effect is the increase of the amount of catalytically active mononuclear complexes $\mathrm{CuL}_{4}(\mathrm{OH}) \mathrm{Cl}$ with increasing $\alpha$ up to $\alpha=0.134$. This is due to a stronger polydentate effect for higher $\alpha$ because of the higher local ligand concentration within the polymer coils, which can be regarded as separate micro-reactors. For $\alpha>0.23$ the interligand distance becomes too short to link adjacent ligands to the same copper ion. Consequently, some ligands have to be skipped in favour of next ones, the strain is somewhat released and the intrinsic activity slightly decreases. For $\alpha \geqslant 0.096$ the phenol oxidation step proved to be rate limiting. However, for very low chain loadings, e.g. $\alpha=0.044$, the local concentration of mononuclear copper complexes within the coils becomes too low and the dimerization which is needed for the $C u(I)$ reoxidation becomes rate determining. The catalytic specificity proved to be independent of $\alpha$ under our reaction conditions.

\section{INTRODUCTION}

Copper complexes of DMAP and "polystyrene-bound DMAP" (structures (1) and (2)

\footnotetext{
* Poly[styrene-co-4-( $N$-methyl- $N$-pvinylbenzylamino)pyridine].

* Paper presented at the ESF Workshop on Reactive Polymers as Supports and Catalysts, Tirrenia, Italy. October 1-3, 1986.

*** To whom correspondence should be addressed.
}

in Scheme 1, respectively) proved to be very active and specific catalysts for the oxidative polymerization of 2,6-dimethylphenol (DMP) to polyphenyleneoxide (PPO) [1-3]. Only a minor amount of the undesired by-product diphenoquinone (DPQ) is formed, provided that the reaction conditions are suitably chosen (see Scheme 2).

In a catalytically active solution an equilibrium proved to exist between dinuclear and 


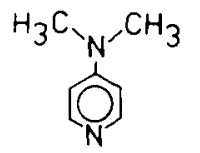

(1)

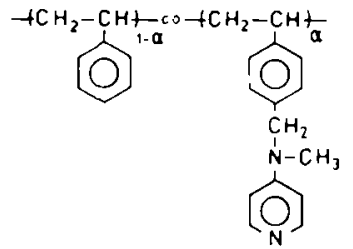

(2)
Scheme 1.

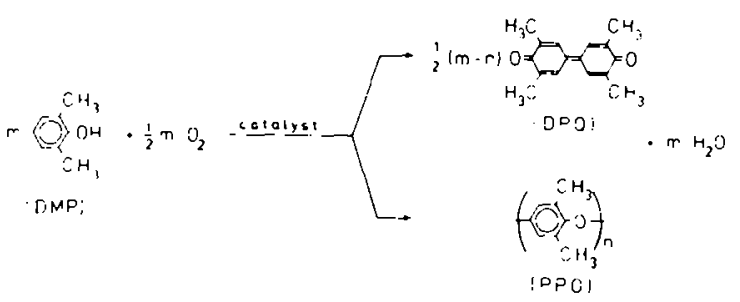

Scheme 2.

mononuclear copper-DMAP complexes $[2,3]$. The concentration of the mononuclear species $\mathrm{Cu}(\mathrm{II}) \mathrm{L}_{4}(\mathrm{OH}) \mathrm{Cl}$ (where $\mathrm{L}=$ DMAP for both (1) and (2) in Scheme 1) increases on enhancing the ratio $\mathrm{L} / \mathrm{Cu}$. A higher $\mathrm{Cu}(\mathrm{II}) \mathrm{L}_{4}(\mathrm{OH}) \mathrm{Cl}$ concentration yields a higher activity of the catalyst solution. Actually, for $\mathrm{L} / \mathrm{Cu}=4$ and $(\mathrm{OH} / \mathrm{Cu})_{0}=1$ and using standard conditions the only spectroscopically detectable species is this mononuclear species. Furthermore, it was found that for the reoxidation of mononuclear $\mathrm{Cu}(\mathrm{I})$ complexes, which are formed from mononuclear $\mathrm{Cu}(\mathrm{II})$ complexes when DMP is oxidized, dimerization of these complexes is needed [2,3].

In comparing the polymer-bound $\mathrm{Cu}(\mathrm{II})-$ DMAP catalyst ( $\mathrm{Cu}(\mathrm{II})-\mathrm{PS}-\mathrm{DMAP})$ with its low molar mass analogue (Cu(II)-DMAP), several polymer effects were observed [3]. Extensive descriptions of polymer chain effects were given for example, by Pittman [4], Ciardelli et al. [5] and Bootsma and Challa [6]. An important polymer effect which was observed in our system was the higher catalytic activity of the polymer catalyst, for which several reasons can be given. First, the polymer chain plays an important role in the reoxidation of mononuclear $\mathrm{Cu}(\mathrm{I})$ complexes (see above). For the low molar mass $\mathrm{Cu}$ (II) DMAP complexes this reoxidation of $\mathrm{Cu}(\mathrm{I})$ to $\mathrm{Cu}(\mathrm{II})$ is rate limiting at our standard conditions, and a second-order rate dependence on $[\mathrm{Cu}(\mathrm{II})]_{0}$ is observed. For the polymer-bound catalyst the $\mathrm{Cu}(\mathrm{I})$ dimerization, and thus the reoxidation to $\mathrm{Cu}(\mathrm{II})$, is promoted by the high local copper concentration in the polymer coils. In addition, the rate constant for the electron transfer in the reoxidation to $\mathrm{Cu}(\mathrm{II})$ may be enhanced by the nonpolar field which is created by the polymer backbone [7]. Consequently, for the polymer catalyst the $\mathrm{Cu}(\mathrm{I})$ reoxidation is no longer rate limiting and real DMP oxidation rates are measured under standard conditions. Moreover, the polymer chain has some accelerating effects on the oxidation of DMP as well. Thanks to the high local DMAP concentration in the polymer coil the stability of Cu(II)-PS-DMAP towards, for example, an excess of hydroxide is higher [2] and the coordination of one $\mathrm{Cu}(\mathrm{II})$ ion by four ligands can occur very effectively. This phenomenon is called the "polydentate effect," and good examples of it were reported by Nishikawa and Tsuchida [8] and Challa [9]. An important consequence of the high local ligand concentration is that, for a given $\mathrm{L} / \mathrm{Cu}$ ratio, the concentration of the catalytically highly active mononuclear species $\mathrm{Cu}(\mathrm{II}) \mathrm{L}_{4}(\mathrm{OH}) \mathrm{Cl}$ is higher in the case of $\mathrm{Cu}(\mathrm{II})$-PS-DMAP and thus a higher activity in the DMP oxidation may be expected (see above). As an illustration the absorbance of mononuclear complexes, $A_{\mathrm{Cu}(\mathrm{II}) \mathrm{L}_{4}(\mathrm{OH}) \mathrm{Cl}}$, is drawn in Fig. 1 as a function of $\mathrm{L} / \mathrm{Cu}$ for both polymerbound and unbound copper-DMAP complexes. Most catalytic experiments were carried out at $\mathrm{L} / \mathrm{Cu}=4$. At this $\mathrm{L} / \mathrm{Cu}$ ratio a difference in the concentration of the active species for the DMP oxidation is obvious, but it can hardly account for the large difference in activity (measured as $\mathrm{O}_{2}$ uptake) observed at $\mathrm{L} / \mathrm{Cu}=4$ (see also Fig. 1 ).

Challa and coworkers have reported 


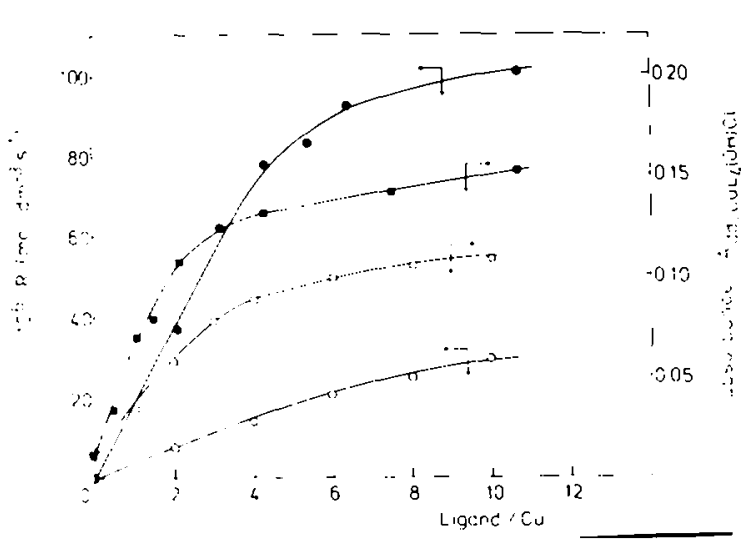

Fig. 1. Dioxygen consumption rate $R$ as a function of L. Cu for PS-DMAP (0. $\alpha=0.251$ ) and DMAP (O) and the visible absorbance of the mononuclear complex

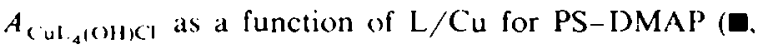
$\alpha=0.251 . \lambda_{\max }=636 \mathrm{~nm}$ ) and DMAP ([]. $\lambda_{\text {max }}=630$ $\mathrm{nm})$. Standard conditions with $(\mathrm{OH} / \mathrm{Cu})_{0}=1(\square$ and $\square$ without IDMP).

another, very interesting polymer chain effect for several polymer-copper catalysts in the oxidative coupling of 2,6-disubstituted phenols, viz., for copper complexes based on polymer-bound dimethylamines, polymerbound pyridines and polymer-bound imidazoles $[10,11]$. This chain effect proved to accelerate the DMP oxidation step by strain in the intermediate chain segments linking neighbouring amine ligands coordinated in the same copper complex. The observed acceleration proved to increase with the chain loading, $\alpha$. In our previous study on polymeric copper DMAP complexes a similar effect was observed [2].

Reconsidering Fig. 1 it seems that the major factors determining the high activity of the polymer catalyst with respect to its low molar mass analogue must originate from the acceleration of the $\mathrm{Cu}(\mathrm{I})$ reoxidation and from the above-mentioned strain in the polymeric catalyst.

Usually. with Cu(II)-PS DMAP catalysts. Michaelis-Menten kinetics in terms of the substrate DMP are obeyed in the oxidative

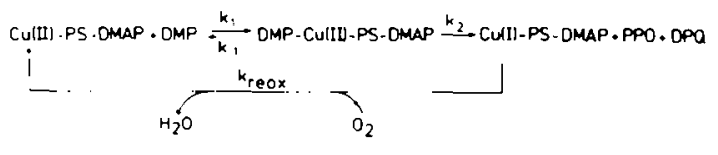

Scheme ?.

polymerization [1.2] (see Scheme 3). Thus, Lineweaver-Burk plots of $R^{-1}$ versus $[\mathrm{IMMP}]^{-1}$ yield straight lines intersecting the $y$-axis according to the equation:

$$
\frac{1}{R}=\frac{1}{k_{2}[\mathrm{Cu}(\mathrm{II})]_{0}}+\frac{K_{\mathrm{m}}}{k_{2}[\mathrm{Cu}(\mathrm{II})]_{03}[\mathrm{DMP}]_{0}}
$$

In eqn. (1). $K_{\mathrm{m}}$ is the Michaelis constant $\left(=\left(k_{1}+k_{2}\right) / k_{1}\right), k_{2}$ is the rate constant of the rate-limiting oxidation of IDMP and $k_{2}[\mathrm{Cu}(\mathrm{II})]_{0} \equiv R_{\max }$ is the dioxygen consumption rate at infinite DMP concentration.

In this paper, a detailed investigation of the " $\alpha$-effect" in catalysis using (u(II)-PS DMAP is reported. For this purpose, $R_{\max }$ has been determined as a function of the chain loading, $\alpha$. Supporting $\mathrm{LV} / \mathrm{V}$ is experiments were carried out in order to help to explain the catalytic results obtained.

\section{EXPERIMENTAI.}

\section{Materials}

For catalytic and spectroscopic experiments. 1.2-dichlorobenzene, $\mathrm{KOH}$ and $\mathrm{CuCl}_{2}$ - $2 \mathrm{H}_{2} \mathrm{O}$ were from Merck and analytically pure. The copper salt and the hydroxide were used as methanolic solutions in which the methanol was of Uvasol quality from Merck. 2.6-Dimethylphenol was from Aldrich and was purified by recrystallization from n-hexane.

For the syntheses described below, all chemicals were chemically pure and used without further purification. 
Synthesis of 4-( N-methyl-N-p-vinylbenzylamino)pyridine (3)

Monomer (3) was synthesized mainly as described before [2], viz., by a slight modification of the method of Tomoi et al. [12]. Improvements are described below. These concern the chloromethylation of 2-phenylethyl bromide and the synthesis of 4- $N$ methylamino)pyridine.

An amount of $178.4 \mathrm{~g}(0.96 \mathrm{~mol})$ of 2-phenylethyl bromide was chloromethylated by the method of Galeazzi [13]. $350 \mathrm{ml}$ of 1,2-dichloroethane was added to dilute the reaction mixture. The reaction was carried out at $30^{\circ} \mathrm{C}$ and the conversion was followed by recording the $\mathrm{IR}$ absorption of $\mathrm{CH}_{2} \mathrm{Cl}$ at $675 \mathrm{~cm}^{-1}$. After 7 days the reaction was stopped, and $114.5 \mathrm{~g}(0.49 \mathrm{~mol})$ of pure $p$ - $(2$ bromoethyl) benzyl chloride was isolated from the $o, p$-product mixture as described by Kondo et al. [14] (Yield: 51\%; m.p. $49.5-52^{\circ} \mathrm{C}$, lit. [14] m.p. $\left.48-50^{\circ} \mathrm{C}\right)$. Subsequently $p$-(2-bromoethyl)benzyl chloride was transformed into $p$-chloromethylstyrene as described previously [14].

4-( $N$-Methylamino)pyridine was synthesized in aqueous solution as described by Wibaut and Broekman [15]. 4-Chloropyridine hydrochloride was used instead of 4-chloropyridine and the reaction was carried out under $\mathrm{N}_{2}$ in sealed Carius tubes $\left(155^{\circ} \mathrm{C} ; 12\right.$ h). After working up the product it was treated with activated charcoal and recrystallized from diethyl ether. The yield was $70 \%$, m.p. $124-126^{\circ} \mathrm{C}$ (lit [15] m.p. $124.5-125^{\circ} \mathrm{C}$ ).

The reaction of $p$-chloromethylstyrene with the sodium salt of 4-( $N$-methylamino)pyridine as well as the purification of monomer (3) were carried out as described previously [2], and pure monomer (3) was obtained in $90 \%$ yield.

Synthesis and characterization of polystyrenebound DMAP (2)

Linear polystyrene-bound DMAP (2) was prepared as described before by radical copolymerization of styrene and 4-( $N$-methyl$N$-p-vinylbenzylamino)pyridine (3) using AIBN as an initiator [2]. The polymers were precipitated in petroleum-ether $(40 / 60) /$ diethyl ether $=2 / 1(v / v)$ and reprecipitated twice from chloroform in petroleum-ether $(40 / 60) /$ diethyl ether $=2 / 1$ $(\mathrm{v} / \mathrm{v})$.

Number-average molar masses, $\bar{M}_{\mathrm{n}}$, were determined in chloroform with a Knauer membrane osmometer. The degree of functionalization $(\alpha)$ of the synthesized polymers was determined by elemental analysis. For details concerning the polymerizations and the characterizations of the polymers the reader is referred to the Results Section (below and Table 1).

\section{Oxidative coupling}

The standard conditions for oxidative coupling were: $T=298.2 \mathrm{~K},[\mathrm{Cu}(\mathrm{II})]=8.3 \times 10^{-4}$

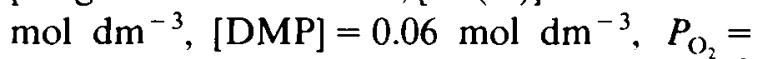
$101.3 \mathrm{kPa}$, total reaction volume $=0.015 \mathrm{dm}^{3}$, solvent mixture 1,2-dichlorobenzene/metha$\mathrm{nol}=13 / 2(\mathrm{v} / \mathrm{v})$. The polymeric catalyst was prepared in situ by dissolving the polymer ligand (2) in 1,2-dichlorobenzene and adding methanolic solutions of $\mathrm{CuCl}_{2} \cdot 2 \mathrm{H}_{2} \mathrm{O}$ and $\mathrm{KOH}$ in the optimum ratio of $(\mathrm{OH} / \mathrm{Cu})_{0}=1$ [2]. The reaction vessel was connected with an automatic gas burette with pure dioxygen [16]. After saturating the catalyst solution with dioxygen the reaction was started by addition of DMP. The vessel was vigorously shaken in a thermostatted bath, and the dioxygen consumption was recorded at constant pressure as a function of reaction time. The steady-state reaction rate, $R$, was calculated from the maximum slope of the dioxygen consumption curve.

Determination of catalytic specificity of the complexes

In order to determine the catalytic specificity for PPO formation some reactions were 
run to completion and aliquots of the reaction mixture were diluted with solvent mixture. The concentration of the only and undesired by-product diphenoquinone (DPQ) in these diluted mixtures was determined with a Pye Unicam SP 8-200 UV/Vis spectrophotometer at $426 \mathrm{~nm}\left(\epsilon=61,000 \mathrm{dm}^{3} \mathrm{~mol}^{-1}\right.$ $\mathrm{cm}^{-1}$ ). From these data the percentage of DMP that had been transformed into DPQ was calculated.

Spectroscopic analysis of the polymeric $\mathrm{Cu}(I I)$ complexes

$\mathrm{UV} / \mathrm{Vis}$ spectra of solutions of the polymeric $\mathrm{Cu}(\mathrm{II})$ complexes were recorded on a Pye Unicam SP 8-200 UV/Vis spectrophotometer at $298.2 \mathrm{~K}$.

\section{RESULTS}

\section{Polymerizations}

In Table 1 data concerning the syntheses and characterizations of the PS DMAP ligands used in this paper are given.

The polymers with $\alpha=0.222$ and $\alpha=0.237$ were obtained from the same reaction mix-

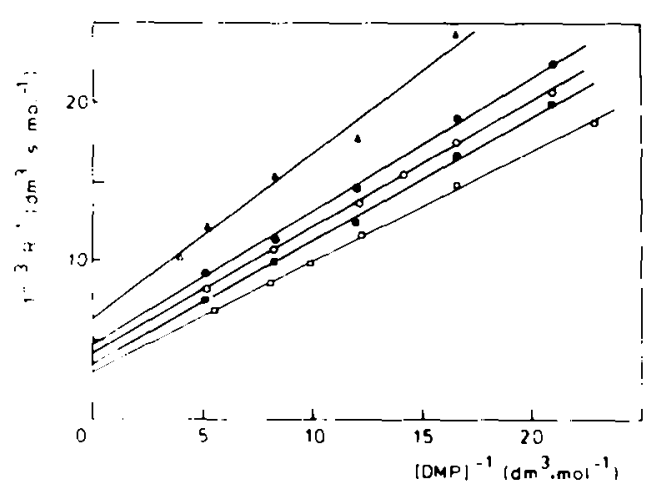

Fig. 2. Lineweaver-Burk plots of $R^{1}$ versus [DMP] for some PS-DMAP ligands. Standard conditions with $\mathrm{L} / \mathrm{Cu}=4$ and $(\mathrm{OH} / \mathrm{Cu})_{0}=1$. ( $\left.\Delta\right) \alpha=0.044$; (ब) $\alpha=$ 0.096: (○) $\alpha=0.134$; (口) $\alpha=0.187$; (口) $\alpha=0.251$. ture. The polymerization was started and after $1 \mathrm{~h}$ half of the reaction mixture was precipitated under a nitrogen atmosphere. The conversion of the polymerization proved to be not much higher than $5 \%$ (see Table 1). The chain loading of the purified sample was $\alpha=$ 0.237 . The remaining half of the initial polymerization mixture was allowed to polymerize for another $64 \mathrm{~h}$, resulting in a polymer with $\alpha=0.222$. In this case the conversion was at least $60 \%$. The results of these experiments may indicate that a rather random copolymer is formed, even for high conversions of the polymerizations. No attempts were undertaken to determine the exact reactivity ratios of styrene and monomer (3).

\section{Catalysis and specificity of PPO formation}

For all polymer ligands listed in Table 1 the dioxygen consumption rate $R$ was determined as a function of the DMP concentration. Standard conditions were used with $\mathrm{L} / \mathrm{Cu}=4$ and $(\mathrm{OH} / \mathrm{Cu})_{0}=1$. Lineweaver-Burk plots of $R^{-1}$ versus [DMP] " for these polymer catalysts yielded straight lines intersecting the $y$-axis, indicating that for all investigated chain loadings $\alpha$, Michaelis Menten kinetics in DMP are valid. For some $\alpha$ values the plots of $R^{-1}$ versus $[\mathrm{DMP}]^{-1}$ are shown in Fig. 2.

For $\alpha \geqslant 0.096$ an increase of $P_{0}$, from $101.3 \mathrm{kPa}$ to $131.7 \mathrm{kPa}$ did not affect $R$ within experimental error. indicating that under the conditions which were used to construct Fig. 2 DMP oxidation rates are measured rather than $\mathrm{Cu}(\mathrm{I})$ reoxidation rates. This was also observed by Verlaan et al. [1] for an almost identical system with $\mathrm{L} / \mathrm{Cu}=2$ for $0.056 \leqslant \alpha \leqslant 0.173$. For our copolymer with $\alpha=0.044$, however, an increase of $P_{0}$, by a factor 1.3 resulted in a $17 \%$ increase of $R$, which is far beyond experimental error. More attention to this point will be given below.

From the intercepts of all constructed Lineweaver-Burk plots. $R_{\max }$ was determined. 
TABLE 1

Data on the synthesis and characterization of polymers (2) with varying chain loading $\alpha$. The polymerizations were carried out under $\mathrm{N}_{2}$ at $75-80^{\circ} \mathrm{C}$

\begin{tabular}{llllllll}
\hline $\begin{array}{l}\text { Amount of } \\
\text { monomer } \\
(3)(\mathrm{g})\end{array}$ & $\begin{array}{l}\text { Amount of } \\
\text { styrene }\end{array}$ & $\begin{array}{l}\text { Mol \% of } \\
\text { AIBN }\end{array}$ & $\begin{array}{l}\text { Amount of } \\
\text { toluene } \\
(\mathrm{g})\end{array}$ & $\begin{array}{l}\text { Polyme- } \\
\text { rization } \\
\text { time }(\mathrm{h})\end{array}$ & $\begin{array}{l}\text { Yield of } \\
\text { polymer } \\
(\mathbf{2})(\mathrm{g})\end{array}$ & $\begin{array}{l}\text { Chain } \\
\text { loading, } \\
\alpha\end{array}$ & $\begin{array}{l}\bar{M}_{\mathrm{n}} \\
\left(\mathrm{g} \mathrm{mol}{ }^{-1}\right)\end{array}$ \\
\hline 3.00 & 35.60 & 1.0 & 30.0 & 40 & 22.7 & 0.044 & $2.2 \times 10^{4}$ \\
0.65 & 3.02 & 1.0 & 11.0 & 40 & 2.2 & 0.096 & $4.0 \times 10^{4}$ \\
0.91 & 2.59 & 1.0 & 10.5 & 40 & 2.1 & 0.134 & $3.3 \times 10^{4}$ \\
1.21 & 2.39 & 1.0 & 10.8 & 40 & 2.1 & 0.187 & $4.3 \times 10^{4}$ \\
2.16 & 3.80 & 1.0 & 17.4 & 65 & 3.6 & 0.220 & $3.6 \times 10^{4}$ \\
1.03 & 1.91 & 1.0 & 8.7 & 65 & 1.8 & 0.222 & $3.3 \times 10^{4}$ \\
1.03 & 1.91 & 1.0 & 8.7 & 1 & 0.09 & 0.237 & $?$ \\
2.00 & 3.33 & 1.0 & 17.0 & 65 & 3.2 & 0.224 & $3.3 \times 10^{4}$ \\
10.30 & 18.10 & $\mathrm{~b}$ & 22.4 & 65 & 2.0 & 0.233 & $9.4 \times 10^{4}$ \\
5.28 & 7.34 & 1.0 & 38.1 & 40 & 8.9 & 0.251 & $4.0 \times 10^{4}$ \\
1.73 & 2.42 & 1.0 & 13.0 & 40 & 2.4 & 0.251 & $6.4 \times 10^{4}$ \\
1.61 & 2.70 & 1.0 & 13.0 & 40 & 1.4 & 0.259 & $4.4 \times 10^{4}$ \\
2.36 & 2.82 & 1.0 & 13.0 & 40 & 3.0 & 0.283 & $5.6 \times 10^{4}$ \\
19.33 & 23.54 & 0.3 & 39.0 & 65 & 27.2 & 0.288 & $12.4 \times 10^{4}$ \\
7.25 & 6.60 & 0.33 & 34.8 & 65 & 7.6 & 0.357 & $5.9 \times 10^{4}$ \\
\hline
\end{tabular}

a Based on total monomer.

b $4.8 \mathrm{~g}$ of silica-bound radical initiator (synthesized according to Fery et al. [17] on Aerosil 200 V, Degussa) was used containing ca. $0.02 \mathrm{mmol}$ initiator $/ \mathrm{g}$ silica.

c Unbound polymer (2) produced during the grafting procedure.

In Fig. 3, $R_{\max }$ is drawn as a function of the chain loading, $\alpha$. It is obvious that an optimum intrinsic activity is achieved for $\alpha=$ $0.23( \pm) 0.03$.

In Table 2, the percentage of DMP that is transformed into PPO (after 100\% reaction

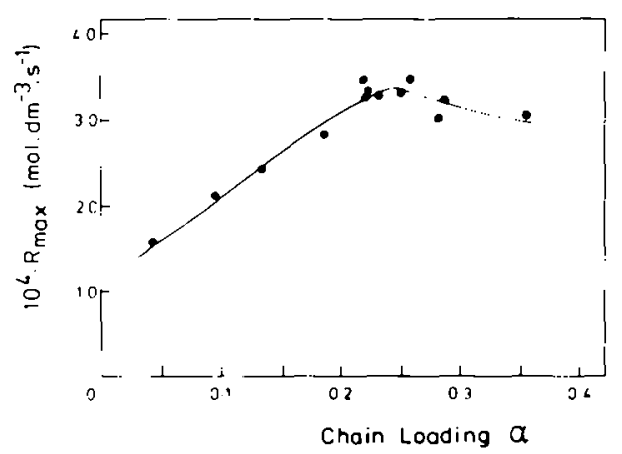

Fig. 3. $R_{\max }$. derived from Lineweaver-Burk plots like those drawn in Fig. 2, versus the chain loading $\alpha$. Standard conditions with $\mathrm{L} / \mathrm{Cu}=4$ and $(\mathrm{OH} / \mathrm{Cu})_{0}=1$. conversion) is given for several values of $\alpha$. It is clear that the specificity of the polymerbound DMAP-copper catalysts is not influenced by the chain loading, and only slightly by the $\mathrm{L} / \mathrm{Cu}$ ratio.

\section{TABLE 2}

Catalytic specificity determined at full conversion of the complexes $\mathrm{Cu}(\mathrm{Il})-\mathrm{PS}-\mathrm{DMAP}$ with varying chain loading $\alpha$. Standard conditions with $(\mathrm{OH} / \mathrm{Cu})_{0}=1$

\begin{tabular}{lll}
\hline $\begin{array}{l}\text { Chain } \\
\text { loading, } \alpha\end{array}$ & $\begin{array}{l}\text { \% PPO for } \\
\mathrm{L} / \mathrm{Cu}=4\end{array}$ & $\begin{array}{l}\text { \% PPO for } \\
\mathrm{L} / \mathrm{Cu}=10\end{array}$ \\
\hline 0.044 & 87 & 92 \\
0.096 & 89 & 92 \\
0.134 & 89 & 92 \\
0.187 & 88 & 92 \\
0.251 & 88 & 92 \\
0.283 & 88 & 92 \\
0.288 & 86 & 93 \\
0.357 & 87 & 91 \\
\hline
\end{tabular}


Reaction order with respect to copper

Relevant for the discussion of the $\alpha$-effect is the following. For the low molar mass catalyst it was found that at standard conditions the $\mathrm{Cu}(\mathrm{I})$ reoxidation is second order with respect to copper [3]. For this system at standard conditions an increase in $P_{0}$, leads to a significant increase in $R$. On the contrary. recent experiments have convinced us that IMP oxidation rates are first order with respect to copper. This was found by determining the order with respect to copper within the polymer coils at standard conditions for PS DMAP with $\alpha=0.251$ [18]. The number of polymer coils was kept constant and the amount of copper ions per coil was varied. However, if the amount of copper ions within a coil became too small, i.e., if the local copper concentration within the coils became too small. then a second-order rate dependence on copper was found and the $\mathrm{Cu}(\mathrm{I})$ reoxidation again proved to be rate limiting! So, for PS-DMAP with $\alpha=0.044$ a significant dioxygen pressure dependence of $R$ is observed (see earlier), which was absent for $\alpha \geqslant 0.096$, where pure DMP oxidation rates are measured. In this respect it is important to note that. for the copper amounts for which a second-order rate dependence within the coil with $\alpha=0.251$ is observed. the average number of $\mathrm{Cu}(\mathrm{II})$ ions per polymer coil is still 3-5. Even for the low molar mass PS DMAP with $\alpha=0.044$ and standard conditions 2-3 Cu((II) ions are present per coil.

\section{LV/Vis-spectroscopic study of complex struc- tures in solution}

$\mathrm{UV} / \mathrm{Vis}$ spectra may give an indication of the composition of the complexes in solution. Hence. spectra were recorded of solutions of copper complexes based on polymer (2) with varying $\mathrm{L} / \mathrm{Cu}$ values.

For both the low molar mass Cu(II) DMAP catalyst [3] and the polymeric $\mathrm{Cu}(\mathrm{II})-$

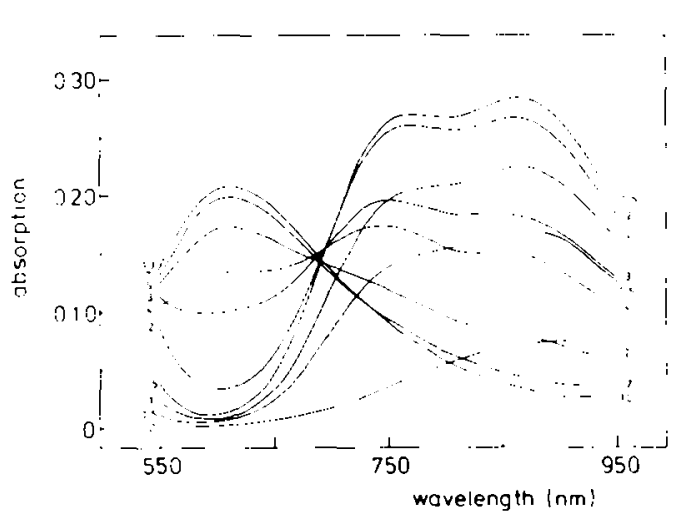

Fig. 4. d-d Absorption spectra for various $L / C$ u values for PS-IDMAP with $\alpha=0.357$. Standard conditions. No hydroxide and DMP were added. I./ $\mathrm{Cu}$ values are indicated in figure.

PS DMAP catalyst with $\alpha=0.251$ [2] the $\mathrm{d}-\mathrm{d}$ absorption spectra were found to be located in the visible region. In Fig. 4 the $d-$-d absorption spectra for the polymeric $\mathrm{Cu}(\mathrm{II})$ PS-DMAP complex with $\alpha=0.357$ are drawn for $0 \leqslant \mathrm{~L} / \mathrm{Cu} \leqslant 10$. In this case no hydroxide was added. Double maxima around $800 \mathrm{~nm}$ are observed for $\mathrm{L} / \mathrm{Cu} \leqslant 4$ as for the polymer ligand with $\alpha=0.251$ [2]. For our polymeric ligand with $\alpha=0.044$. however. double maxima around $800 \mathrm{~nm}$ are observed for $\mathrm{L} /$ $\mathrm{Cu} \leqslant 6$ as for the low molar mass catalyst [3]. A detailed study has taught that these double maxima can be attributed to EPR-silent complexes, probably dinuclear or polynuclear Cu(II)-DMAP species [2,3]. For $\alpha=0.357$ and $(\mathrm{OH} / \mathrm{Cu})_{0}=0$ an isosbestic point is observed for $\mathrm{L} / \mathrm{Cu} \geqslant 1.5$, suggesting that for these values of $\mathrm{L} / \mathrm{Cu}$ one "coloured" species. namely a di- or polynuclear species with $\lambda_{\text {niax }}$ $=800 \mathrm{~nm}$. is transformed into another coloured species with $\lambda_{\max }=630 \mathrm{~nm}$. In our previous work we could prove that the single-topped absorptions around $630 \mathrm{~nm}$ can be ascribed to mononuclear copper complexes with the formula $\mathrm{CuI}_{4} \mathrm{Cl}_{2}[2.3]$. For the low molar mass catalyst an isosbestic point was found for $\mathrm{L} / \mathrm{Cu} \geqslant 2$.

In Fig. 5, the $d-d$ absorption spectra for the polymer ligand with $\alpha=0.357$ and 


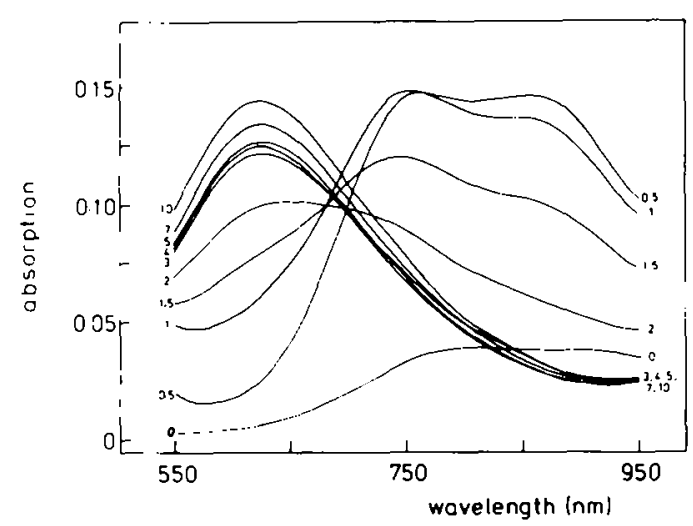

Fig. 5. $d-d$ Absorption spectra for various $L / C u$ values for PS-DMAP with $\alpha=0.357$. Standard conditions with $(\mathrm{OH} / \mathrm{Cu})_{0}=1$. No DMP was added. $\mathrm{L} / \mathrm{Cu}$ values are indicated in figure.

$(\mathrm{OH} / \mathrm{Cu})_{0}=1$ are drawn for various values of $\mathrm{L} / \mathrm{Cu}(0 \leqslant \mathrm{~L} / \mathrm{Cu} \leqslant 10)$. In this case the transition of di- or polynuclear into mononuclear $\mathrm{Cu}(\mathrm{II})$-DMAP complexes already takes place for $\mathrm{L} / \mathrm{Cu} \geqslant 1$. Dinuclear complexes are present in reasonable amounts only for $\mathrm{L} / \mathrm{Cu} \leqslant 2.0(\leqslant 3$ for $\alpha=0.044)$. In this case the single absorption maxima around $630 \mathrm{~nm}$ are attributed to the mononuclear species $\mathrm{CuL}_{4}(\mathrm{OH}) \mathrm{Cl}[2,3]$.

From the above it is clear that in the presence of hydroxide the dinuclear $\mathrm{Cu}(\mathrm{II})$ - DMAP complexes have already ceased to exist at lower $\mathrm{L} / \mathrm{Cu}$ values than in the absence of hydroxide. Moreover, in the presence of hydroxide the isosbestic point becomes less well defined for higher $\mathrm{L} / \mathrm{Cu}$ values for which dinuclear complexes are no longer present in the solution (see Fig. 5). Both effects were reported before [2,3]. They can be explained by assuming that $\mathrm{Cu}(\mathrm{II})$ is partly present in polynuclear hydroxidebridged $\mathrm{Cu}(\mathrm{II})$ species: $\mathrm{Cu}\left[(\mathrm{OH})_{2} \mathrm{Cu}\right]_{n}$. It is known that such copper compounds can be readily formed in solvents other than water [19]. As long as dinuclear complexes exist in solution an increase of $\mathrm{L} / \mathrm{Cu}$ causes a transformation of dinuclear complexes into mononuclear ones and the isosbestic point is sharp.
However, when the dinuclear complexes are exhausted the observed increase of $\left[\mathrm{CuL}_{4}(\mathrm{OH}) \mathrm{Cl}\right]$ with the increasing $\mathrm{L} / \mathrm{Cu}$ ratio must be brought about by taking away copper ions from the spectroscopically undetectable polynuclear copper compounds, and an isosbestic point can no longer be observed. The consequence of the existence of such compounds in the reaction mixture is a high effective value of $\mathrm{L} / \mathrm{Cu}$, as part of the copper ions is poorly accessible for the offered DMAP ligands. Consequently, for comparable $(\mathrm{L} / \mathrm{Cu})_{0}$ the equilibrium between $\mathrm{di}-$. and mononuclear $\mathrm{Cu}(\mathrm{II})$-DMAP complexes is shifted towards the mononuclear complexes in case of added hydroxide. As an illustration the following may serve: for $\alpha=0.357$ with standard conditions, $(\mathrm{L} / \mathrm{Cu})_{0}=1.5$ and $(\mathrm{OH} / \mathrm{Cu})_{0}=2$, only mononuclear complexes are present in solution, whereas Figs. 4 and 5 clearly indicate the presence of dinuclear complexes for $(\mathrm{L} / \mathrm{Cu})_{0}=1.5$ for $(\mathrm{OH} / \mathrm{Cu})_{0}$ $=0$ and 1 , respectively.

In Fig. 6, the $U V / V$ is absorption of the mononuclear complexes $\mathrm{CuL}_{4}(\mathrm{OH}) \mathrm{Cl}$ has been plotted as a function of $\mathrm{L} / \mathrm{Cu}$ for $\alpha=$ $0.044, \alpha=0.251$ and $\alpha=0.357$. For comparison the curve for the low molar mass catalyst

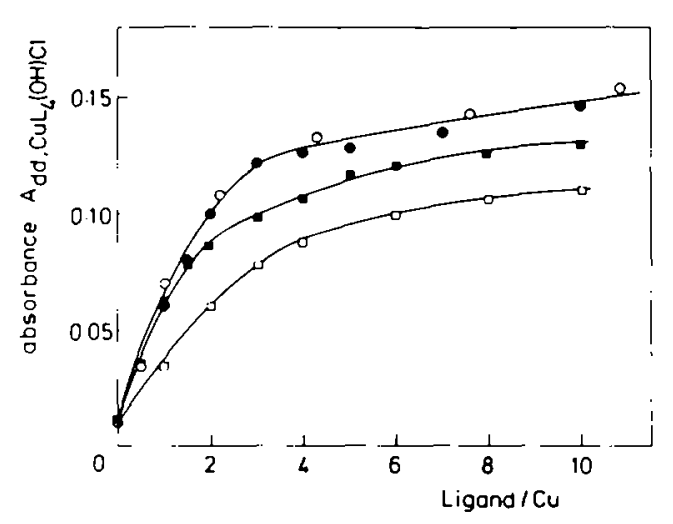

Fig. 6. Visible absorbance of mononuclear complexes, $A_{\text {Cul., (OH)Cl, }}$ as a function of $\mathrm{L} / \mathrm{Cu}$. Standard conditions with $(\mathrm{OH} / \mathrm{Cu})_{0}=1$. No DMP was added. (口) Low molar mass DMAP; ( $\square$ ) PS-DMAP, $\alpha=0.044$; (•) PS-DMAP, $\alpha=0.357$; (O) PS-DMAP, $\alpha=0.251$. Values of $\lambda_{\max }$ are given in Table 3. 


\section{TABLE 3}

Absorption of the mononuclear complex $\mathrm{CuL}_{4}(\mathrm{OH}) \mathrm{Cl}$ around $630 \mathrm{~nm}$ for DMAP and PS-DMAP with different chain loadings $\alpha$. Ligands marked with * have been prepared by Verlaan et al. [1] by reaction of the sodium salt of 4-( $N$-methylamino)pyridine with partially chloromethylated polystyrene. Standard conditions with $\mathrm{L} / \mathrm{Cu}=4$ and $(\mathrm{OH} / \mathrm{Cu})_{0}=1$ and without DMP

\begin{tabular}{lll}
\hline Chain loading & $\lambda_{\max }(\mathrm{nm})$ & $A_{\text {(ul. }_{4}(\mathrm{OH} \times \mathrm{C})}$ \\
\hline DMAP & 630 & 0.088 \\
$0.044^{*}$ & 630 & 0.105 \\
$0.056^{*}$ & 630 & 0.107 \\
$0.134^{*}$ & 630 & 0.124 \\
$0.173^{*}$ & 630 & 0.119 \\
0.187 & 630 & 0.124 \\
0.220 & 626 & 0.120 \\
0.251 & 636 & 0.126 \\
0.283 & 632 & 0.120 \\
0.357 & 635 & 0.125 \\
\hline
\end{tabular}

is given as well. According to Fig. 6 it seems as if the building up of mononuclear $\mathrm{Cu}(\mathrm{II})$ DMAP complexes occurs less easily for low chain loadings $\alpha$. The polydentate effect (see Introduction) seems to be less pronounced in that case. For the low molar mass ligand, of course, no polydentate effect exists at all.

In Table 3, the wavelength and the absorption of the mononuclear complexes $\mathrm{CuL}_{4}(\mathrm{OH}) \mathrm{Cl}$ is given for DMAP and PS DMAP with differing chain loadings $\alpha$. The conditions under which $A_{\mathrm{CuL}_{4}\left(\mathrm{OH}_{\mathrm{HCl}} \text { was }\right.}$ measured conform to those under which the Lineweaver-Burk plots of Fig. 2 were measured, i.e., standard conditions with $\mathrm{L} / \mathrm{Cu}=4$ and $(\mathrm{OH} / \mathrm{Cu})_{0}=1$. No DMP was added. The two PS DMAP ligands marked with superscript asterisks in Table 3 were prepared by Verlaan et al. [1] by reaction of the sodium salt of $4-(N$-methylamino)pyridine with partially chloromethylated polystyrene.

\section{DISCUSSION}

Looking for an explanation of the observed effect of chain loading, one must keep in mind that for the polymer ligand with $\alpha=$ 0.044 no real DMP oxidation rates are measured (see earlier). The $\mathrm{Cu}(\mathrm{I})$ reoxidation is rate determining, and a fair comparison with the polymers with $\alpha \geqslant 0.096$ is impossible. The reason for this is the following. For low chain loadings the distance between the copper ions along the chain is large and the local copper concentration within the coils is relatively low. Accordingly, the dimerization of mononuclear $\mathrm{Cu}(\mathrm{I})$ DMAP complexes. an inevitable step in the $\mathrm{Cu}(\mathrm{I})$ reoxidation $[2.3]$. is retarded and the reoxidation of $\mathrm{Cu}(\mathrm{I})$ becomes rate determining. Exactly the same effect occurs in case of high chain loadings when the amount of copper ions per polymer coil is relatively low. This situation may arise. for example. for low values of $[\mathrm{Cu}(\mathrm{II})]_{0}$. when the order with respect to copper within a polymer coil is determined (see carlier).

For $\alpha \geqslant 0.096$. however. we found that real phenol oxidation rates are measured. In fact. perfect linear relationships between $R \quad$ and [DMP] ${ }^{1}$ are observed (Fig. 2), pointing to Michaelis-Menten kinetics in terms of the substrate.

Now let us consider the spectroscopic results. $R_{\text {max }}$ was determined at standard conditions with $\mathrm{L} / \mathrm{Cu}=4$ and $(\mathrm{OH} / \mathrm{Cu})_{0}=1$. For polymer ligands listed in Table 1 with $\mathrm{L} / \mathrm{Cu}=4$ and $(\mathrm{OH} / \mathrm{Cu})_{0}=1$ the only spectroscopically detectable Cu(II) DMAP complexes present in solution at the moment of DMP addition are the mononuclear species $\mathrm{CuL}_{4}(\mathrm{OH}) \mathrm{Cl}$. From our earlier work we know that a higher initial concentration of $\mathrm{CuL}_{4}(\mathrm{OH}) \mathrm{Cl}$ leads to a higher activity of the catalyst solution [2.3]. Table 3 shows that for $\mathrm{L} / \mathrm{Cu}=4$ and $(\mathrm{OH} / \mathrm{Cu})_{1}=1$ the amount of $\mathrm{CuL}_{4}(\mathrm{OH}) \mathrm{Cl}$ increases with $\alpha$ for $\alpha<0.134$ and levels off for $\alpha \geqslant 0.134$. This increase can be explained by the polydentate effect. which 
is also demonstrated in Fig. 6. A higher chain loading implies a higher local ligand concentration in the polymer coil. Consequently, for a fixed value of $\mathrm{L} / \mathrm{Cu}$ the coordination of $\mathrm{Cu}$ (II) by four DMAP ligands occurs to a larger extent for higher values of $\alpha$. The large difference between $\mathrm{Cu}(\mathrm{II})$-PS-DMAP and the low molar mass catalyst is striking and understandable from this point of view. From the results in Table 3 and Fig. 3 it is obvious that the relatively small increase of the amount of $\mathrm{CuL}_{4}(\mathrm{OH}) \mathrm{Cl}$ with $\alpha$ cannot account for the rather strong increase of $R_{\max }$. Moreover, for $\alpha \geqslant 0.134$ a significant further enhancement of $R_{\max }$ with $\alpha$ is observed while the amount of $\mathrm{CuL}_{4}(\mathrm{OH}) \mathrm{Cl}$ remains constant within experimental error.

For $\alpha \geqslant 0.096$ the increase of $R_{\max }$ with $\alpha$ implies an increase of the DMP oxidation rate. As was mentioned in the Introduction, the strain in the polymeric catalyst may play an important role in the intrinsic activity of the catalyst [9-11]. A similar effect is well known in enzyme catalysis [20] and indicated by the term "entatic state" [21]. The idea is that for an entatic catalyst the activation free energy is reduced relative to a normal catalyst as a result of the strain.

Table 4 shows that, within experimental error, $R_{\max }$ is not influenced by the molar mass of the polydentate for a constant chain loading $\alpha$. An increase of $\bar{M}_{\mathrm{n}}$ with constant $\alpha$ implies a reduction of the number of polymer

\section{TABLE 4}

$R_{\max }$ at standard conditions with $\mathrm{L} / \mathrm{Cu}=4$ and $(\mathrm{OH} / \mathrm{Cu})_{0}=1$ for PS-DMAP-Cu(II) with comparable $\alpha$ but differing $\bar{M}_{\mathrm{n}}$ (values derived from Table 1 and Fig. 3).

\begin{tabular}{lll}
\hline$\alpha$ & $\begin{array}{l}\bar{M}_{\mathrm{n}} \\
\left(\mathrm{g} \mathrm{mol}^{-1}\right)\end{array}$ & $\begin{array}{l}R_{\max } \\
\left(\mathrm{mol} \mathrm{dm}^{-3} \mathrm{~s}^{-1}\right)\end{array}$ \\
\hline 0.224 & $3.3 \times 10^{4}$ & $3.32 \times 10^{4}$ \\
0.233 & $9.4 \times 10^{4}$ & $3.29 \times 10^{4}$ \\
0.283 & $5.6 \times 10^{4}$ & $3.03 \times 10^{-4}$ \\
0.288 & $12.4 \times 10^{4}$ & $3.24 \times 10^{-4}$ \\
\hline
\end{tabular}

coils (and, as a consequence, an increase of the number of copper complexes per coil), while the intermediate chain length between successive DMAP ligands remains the same. On the other hand, an increase of $\alpha$ with (practically) constant $\bar{M}_{\mathrm{n}}$ implies a reduction of the interligand distance, while the number of polymer coils decreases as well. As an increase of $\alpha$ changes the catalytic activity while an increase of $\bar{M}_{\mathrm{n}}$ does not influence $R_{\text {max }}$, it can be concluded that the increase in catalytic activity is determined by the decreasing intermediate chain length between successive DMAP ligands coordinated in the same copper complex and not by the higher total number of copper complexes within one polymer coil for increasing $\alpha$. In going from $\alpha=0.096$ to $\alpha=0.23$ the intermediate chain lengths become shorter, the strain in the catalyst increases and the rate of electron transfer from the substrate to $\mathrm{Cu}(\mathrm{II})$ is enhanced. Challa and coworkers [10,11] found that for copper complexes of polystyrenebound dimethylamines the increase of $k_{2}$ with $\alpha$ is governed by an increase of activation entropy $\Delta S^{\neq}$with $\alpha$ which overcompensates for the retarding effect of a simultaneously increasing $\Delta \mathrm{H}^{\neq}$. This was explained in terms of an increasing number of possible conformations of the intermediate chain segments in the transition state between the $\mathrm{Cu}(\mathrm{II})$ and the $\mathrm{Cu}(\mathrm{I})$ complexes. For high values of $\alpha$ the intermediate chain segments are more strained, and therefore the number of chain conformations increases relatively more strongly when going from the octahedral $\mathrm{Cu}(\mathrm{II})$ to the transition state. After the electron transfer tetrahedrally based $\mathrm{Cu}(\mathrm{I}) \mathrm{com}$ plexes will occur.

The explanation given above was supported by chain statistical calculations and measuring heats of complexation of $\mathrm{Cu}$ (II) with polymers with varying $\alpha$. It seems that the above-mentioned explanation is also valid for the observed effect of chain loading for our catalyst system. An effect of intermediate 
segment length on metal complexation was also reported for poly(amido-amines) by Barbucci et al. [22].

When the intermediate chain length between neighbouring DMAP ligands becomes to) short, i.e. for $\alpha \geqslant 0.23$, then adjacent ligands can no longer coordinate to the same copper ion. Consequently, one ligand has to be skipped in favour of the next one, although from an entropic point of view coordination of an adjacent ligand would be more favourable. Consequently, the strain in the polymer catalyst is lower than one would expect, the accelerating factor vanishes and $R_{\text {max }}$ slightly decreases. In fact. the skipping of ligands can be interpreted as a lowering of the "effective" chain loading. The skipped ligands can coordinate to $\mathrm{Cu}(\mathrm{II})$ ions attached to another region of the polymer backbone. which can be considered as a kind of crosslinking. This also may have a small retarding effect on $R_{\text {max }}$.

Table 2 shows that the catalytic specificity of the (u(II) PS-I)MAP catalysts is, within experimental error. independent of the chain loading. This implies that the macromolecular chain itself does not influence the catalytic specificity, which was also observed for the oxidative coupling of DMP by copper complexes of poly(styrene-co-4-vinylpyridine) [16]. Moreover. our earlier work made clear that. in spite of a differing catalytic activity for (u(II) PS-DMAP and its low molar mass analogue. the specificity of both types of catalysts is exactly the same under comparable reaction conditions [2]. So. it seems plausible that product formation by coupling of oxidized DMP does not take place in the catalyst hut in solution.

\section{REFERENCES}

I I.P.J. Verlaan. P.J.I. Alferink and (3. Challa. Copper complexes of polymer-bound 4-aminopyridine as redex catalysts for the oxidative coupling of 2.6dimethylphenol. I. Mol. Catal., 24 (1984) 235.
2 C.E. Koning, J.J.W. Eshuis, F.J. Viersen and (; Challa, Copper(II) complexes of "polystyrene-bound DMAP": Synthesis, structure and catalytic activity in the oxidative coupling of 2,6-dimethylphenol. Reactive Polym.. 4 (1986) 293.

3 C.E. Koning. G. Challa. F.B. Hulshergen and J. Reedijk. Structure of copper 4-(N. V-dimethylamino)pyridine complexes and their catalytic activ. ity in the oxidative coupling of 2,6-dimethylphenol. J. Mol. Catal. 34 (1986) 355

4 (.U. Pittman. Jr.. Catalysis by polymer-supported transition metal complexes, in: P. Hodge and I.).C. Sherrington (Eds.), Polymer-supported Reactions in Organic Synthesis. Wiley, New York, 1980. Chap. 5

5 F. Ciardelli, (i. Braca. C. Carline. C. Sbrana and C. Valentini, Polymer-supported transition metal catalysts: Fstablished results. limitations and potential developments, J. Mol. (atal.. 14 (1982) 1

6 J.P.C. Bootsma and G. Challa, Macromolecular effects in polymer-supported catalysis. Recl. Trav (him. Pays-Bas, 103 (1984) 177.

7 F. Tsuchida, H. Nishikawa and E: Terada, Heffect of nonpolar field formed by polymer ligand on the oxidation of 2.6-xylenol catalyzed by (u complexes J. Polym. Sci. Polym. Chem. Fd.. 14 (1976) 825.

8 H. Nishikatua and F. Isuchida. Complexation and form of poly(vinylpyridine) derivatives with copper(II) in aqueous solution. J. Phys. (hem. 79 (1975) 2072 .

9 G. Challa, Polymer chain effects in polymeric catalvisis, J. Mol. (atal., 21 (1983) l.

10 (j. Challa. A.J. Schouten, (i. ten Brinke and H.C Meinders. Aninated polystyrene copper complexes. as oxidation catalysts: The effect of the degree of substitution on catalytic activity. in: C.F. Carraher Ir. and $M$. Isuda (Eds.). Modification of Polymers ACS Symposium Series Vo. 121. American (hemical Society. Washington. I)( 1980 . p. 7

11 3. Challa. The effect of polvmer-chain structure on the catalytic activity of polymer copper complexes. Makromol. Chem.. Suppl.. 5 (1981) 70).

12 M. Tomoi. Y. Akada and H. Kakiuchi, Polymersupported bases. 1. Synthesis and catalytic activity of polymer-bound 4-( 1 -benzyl-N-methylamino) puridine. Makromol. Chent. Rapid Commun.. 3 (1982) 537

13 L. (ialearai. (jer. Patent 2.455.946. 1975. and Ital Appl. 31929/73, 1973. Verfahren gur Chlornethy. lierung von Styrol/I)ivinylhenzol-(opolvmeren: (hem. Abstr.. 83 (1975) 148292.

14 S. Kondo, T. Ohtsuka. K. Ogura and K. Tsuda, Convenient synthesis and free-radical copolymerization of p-chloromethylstyrene. I. Macromol. Sci.. (hem.. A13 (1979) 767 . 
15 J.P. Wibaut and F.W. Broekman, The reaction of 4-chloropyridine with some amines, Recl. Trav. Chim. Pays-Bas, 80 (1961) 309.

16 H.C. Meinders, Polymer-copper complexes as homogeneous redox catalysts, Thesis, Groningen, November 1979.

17 N. Fery, R. Laible and K. Hamann, Polyreaktionen an Pigmentoberflächen. III. Mitteilung: Polyreaktionen an $\mathrm{SiO}_{2}$-Oberflächen, Angew. Makromol. Chem., 34 (1973) 81.

18 C.E. Koning, F.J. Viersen, G. Challa and J. Reedijk, A mechanistic study on the oxidation of 2,6-dimethylphenol by DMAP- and "polystyrene-bound
DMAP"-based copper catalysts, J. Mol. Catal., in press.

19 F.G.R. Gimblett, Inorganic Polymer Chemistry, Butterworths, London, 1963, Chap. 3.

20 W.P. Jenks, Catalysis in Chemistry and Enzymology, McGraw-Hill, New York, NY, 1969, Chap. 5.

21 R.J.P. Williams, Metallo-enzyme catalysis: The entatic state, J. Mol. Catal., 30 (1985) 1.

22 R. Barbucci, M. Casolaro, P. Ferruti and V. Barone, Macroinorganics. 8. Chelation of copper(II) ion with some new poly(amido-amines), Polymer, 23 (1982) 148. 